\title{
Considerações acerca da educação através dos provérbios em latim na Baixa Idade Média
}

\author{
ÁLVARO ALFREDO BRAGANÇA JÚNIOR \\ Departamento de Letras Anglo-Germânicas - Setor de Alemão \\ Faculdade de Letras \\ Universidade Federal do Rio de Janeiro
}

RESUMO: Aa contribuição da Idade Média para a organização do pensamento educacional ocidental pode ser depreendida por várias vertentes, desde os curricula das escolas dos mosteiros e das abadias até o sistema das artes liberales universitárias. Entretanto, uma das formas mais eficazes de se fornecer os rudimentos culturais aos discípulos, especialmente os do baixo medievo, assentava-se na compilação de exercícios escolares, usualmente em forma de dísticos rimados, que continham uma fundamentação eminentemente teológica presa aos preceitos da Igreja. Esses futuros clerici, instruidos por tal modelo propedêutico, transmitiriam no púlpito as liçōes passadas por seus mestres. Configurava-se assim a proverbialização oral desses textos escritos em uma prática cotidiana, que unia o educar e o saber ao poder, formalizando através desse modelo instrucional os ideais da alta cúpula da Igreja.

PALAVRAS-CHAVES: Paremiologia medieval; Latim medieval; Baixa Idade Média germanófona; Igreja medieval; História da educação

\section{Introdução}

O mundo intelectual medieval hauria nas fontes clássicas a seiva para a sua ciência. Todas as esferas do saber humano procuravam nos antigos o ponto de partida para suas especulações científicas. Esse ideal de educação, do real ex ducere romano, presentificavase no estudo das auctoritates greco-romanas. Ernest Robert Curtius (1957, p. 60), ao questionar o que a Idade Média buscava nos autores clássicos, responde:

São, em primeiro lugar, para toda a Idade Média, e ainda no século XVI, autoridades científicas. Ainda não há ciência moderna. Aprende-se a medicina em Galeno, a história universal em Orósio. Em vez de muitos exemplos, apenas um. No programa de estudos humanísticos, que Rabelais insere no seu romance, para criticar a educação do fim da Idade Média, está previsto que nenhuma hora do dia se passe sem instrução. Depois do 
repasto de Pantagruel, discutem-se as qualidades de todos os alimentos, aliás em continuação a passagens escolhidas de Plínio, Ateneu, Dioscórides, Júlio Pólux, Porfírio, Opiano, Políbio, Heliodoro, Aristóteles 'e outros'. Durante o passeio, são observadas as plantas, segundo Teofrasto, Marino, Nicander e Macer. Para recreio, sentam-se numa campina e recitam versos das Geórgicas de Virgílio, de Hesíodo e do Rusticus de Policiano.

No campo da literatura, também autores como Ovídio e Horácio eram leituras presentes indispensáveis. Entretanto, o autor de Sulmona e o poeta venusino proporcionavam aos seus leitores muito mais que um mero deleite artístico: desejava-se conhecer a fundo as "lições" morais contidas em seus textos. A máxima horaciana Oderunt peccare boni virtutis amore -"Os bons se aborrecem em cometer faltas por amor da virtude" era constantemente citada e Ovídio foi considerado o poeta sententiarum floribus repletus - "cumulado com a nata das sentenças." (Curtius, 1957, p. 61).

A Idade Média precisava do embasamento clássico, de seu engenho e de seus próceres. Disto resulta, citando Curtius (1957, p. 61), que ela nos legou, "postas em ordem alfabética, coleções de sentenças, em que se misturam pensamento antigo e medieval. Oferecem-nas ao leitor moderno os Lateinische Sprichwörter und Sinnsprüche desMittelalters de Jakob Werner (mais de dois mil e quinhentos números). Essas coleções eram usadas como preparo para o recreio do espírito e da inteligência".

A obra de Jakob Werner, inserida na Sammlung mittellateinischer Texte (Coleção de textos de latim medieval), volume 3 , pertence à tradição paremiológica das grandes compilações de provérbios, que os indexam alfabeticamente e muitas vezes, (não se tratando aqui do caso), os dividem em campos do conhecimento humano. ${ }^{1}$

No século XIX, com a valorização do elemento popular na formação da cultura social, o folclore e as tradições do povo foram objeto de pesquisa, na busca de raízes de uma identidade nacional. $\mathrm{Na}$ Alemanha e na parte de língua alemã da Suíça, terra natal de Werner, o espírito de unidade cultural, alcançado no plano político pela fundação do Império Alemão em 1871, levou grande parte de lingüistas e filólogos a se interessar por traços característicos de um Deutschtum, ("germanismo"). Karl Friedrich Wilhelm Wander organizou e levou ao prelo os 5 volumes de seu Deutsches Sprichwörterlexikon (Léxico dos Provérbios Alemães) entre 1863 e 1880. Ida von Düringsfeld e Otto von Reinsberg-Düringsfeld publicaram os 2 volumes de seus Sprichwörter der germanischen und romanischen Sprachen (Provérbios das línguas germânicas e românicas) entre 1872 e 1875. (Werner, 1912, p. III) Este último trabalho, de cunho comparatista, possibilitaria a abertura para estudos mais específicos sobre outras línguas. A. Otto, com seus Die Sprichwörter und sprichwörtlichen

1 A partir da década de 70 desenvolveu-se, primeiramente na Rússia com Permjakov, a chamada "Pesquisa Empírica de Provérbios" (em alemão empirische Sprichwortforschung), que se caracteriza por uma abordagem metodológica diferente daquela constituída pela mera listagem dos mesmos. Sobre isso ver Grzybek (1991: 243-4) e Grzybek \& Chlosta. In: Proverbium 10 (1993, p. 89-128). 
Redensarten der Römer (Os provérbios e expressões proverbiais dos romanos), de 1890, foi um marco neste sentido. Jakob Werner ocupou-se das parêmias em latim medieval.

As fontes documentais do trabalho de Werner são sete manuscritos, a saber:

a) manuscrito B - A.XI., Biblioteca da Universidade de Basel, Suíça. Werner considera a redação do mesmo como tendo sido feita no primeiro quartel do século XV. Trata-se de uma coleção de, na maioria das vezes, sentenças de duas linhas ordenadas alfabeticamente, ao lado das quais, com frequêencia, a fonte é citada;

b) manuscrito Ba - o mesmo manuscrito, porém, contém entre as folhas 236-283 uma coleção de sentenças, provérbios e citações de escritores clássicos, que, do mesmo modo, são ordenados alfabeticamente. O citado manuscrito apresenta-se acrescido de aditamentos;

c) manuscrito D - Darmstadt 2225, século XV (na capa, ano de 1410). Aqui temos o autor da seleção, Galfrido de Vino;

d) manuscrito K - Munique, Biblioteca do Paço, século XIII;

e) manuscrito $\mathbf{P}$ - Paris, Biblioteca Nacional, Lat. 6765, século XII;

f) manuscrito Sch - Munique, Biblioteca do Paço e da Cidade, século XII;

g) manuscrito SG - de Sankt Gallen, Biblioteca do Convento, século XV (1462).

No cômputo geral, há quatro manuscritos, que podem ser datados do século XV, dois manuscritos do século XII e apenas um proveniente do século XIII. O estudioso suíço arrola 2533 provérbios, dentre os quais 1322 rimados, ordenando-os a partir de sua primeira letra, não separando aqueles iniciados por $i$ e $j$ e $u$ e $v$. A incidência de provérbios por letra é a seguinte:

Letra A: 146 ocorrências;

Letra B: 33 ocorrências;

Letra C: 221 ocorrências;

Letra D: 189 ocorrências;

Letra E: 154 ocorrências;

Letra F: 86 ocorrências;

Letra G: 36 ocorrências;

Letra H: 55 ocorrências;

Letras I e J: 159 ocorrências;

Letra L: 77 ocorrências;

Letra M: 104 ocorrências;

Letra N: 307 ocorrências;

Letra O: 101 ocorrências;

Letra P: 150 ocorrências;

Letra Q: 223 ocorrências:

Letra R: 83 ocorrências;

Letra S: 211 ocorrências; 


\section{Letra T: 53 ocorrências;}

Letras U e V: 145 ocorrências.

Este opúsculo do estudioso suíço resume, por fim, condensando em suas cento e doze páginas, as lições culturais de quatro séculos da Baixa Idade Média. Servindo como instrumento didático para os alunos das escolas e universidades de então, os proverbia funcionavam como elementos propedêuticos, não somente do latim, ou de figuras de linguagem, de retórica ou de adorno poético (como a rima), porém essencialmente, de todo um legado universal embasado pela Verdade cristã, condutora do homem durante sua existência terrena.

\section{A rima como traço medieval}

Karl Langosch (1988, p. 67-68) assim sintetiza a função da rima na poesia latina medieval:

Não se pode de antemão menosprezar a rima como artificial ou incômoda e desvalorizá-la face à poesia não rimada; pelo contrário, ela precisa ser considerada como ornamento, cuja colocação exige do poeta numa escala considerável um esforço suplementar, especialmente quando ele lida com ela artisticamente, isto é, ele se esforça em não utilizar tão frequientemente a mesma palavra e a mesma rima, em não deixar o sentido sucumbir à obrigação da rima, mas em jogar engenhosamente com a rima e fortalecer a arte.

A poesia rimada estava, então, em voga, sendo comum a recorrência ao seu uso. Como afirma Maurice Hélin (1972, p. 71), a vitalidade deste tipo de fazer poético espalhouse por entre as camadas cultas do populus, se entendemos cultura aqui no sentido da ambiência intelectual medieval das universidades e escolas monacais, podendo ser, em termos, a ela aplicada, com uma acepção que envolvia toda aquela comunidade lingǘstica, o adjetivo "popular":

Poesia popular? A expressão não é feliz, já que o latim não era nada mais que a língua dos clérigos. Contudo, ela contém uma parte de verdade, se por isso se entende que esta poesia estava adaptada ao novo estágio do latim praticado dentro do meio letrado e pelos homens da Igreja, sem dúvida ambientes restritos, porém muito ativos e possuidores do quase monopólio da cultura.

Este jogo artificial e pensado com a linguagem poética condizia, portanto, com as aspirações dos magistri medievais, ao oferecerem aos seus discipuli a oportunidade de estudar e aprender com as auctoritates da ciência na Antiguidade, aprimorando o domínio do código escrito e internalizando as lições dos mestres do passado.

Curtius (1957, p. 60), após citar as "autoridades científicas" da Idade Média, assim sumariza o seu valor para a época: 
Os autores, todavia, não são somente fontes de saber; são um tesouro da ciência e filosofia da vida. Encontravam-se nos poetas antigos centenas e milhares de versos, que ofereciam, em forma condensada, experiências psicológicas e regras de vida. ... Quintiliano chamava-lhes 'sentenças' (propriamente: 'juízos') por se assemelharem às decisões das corporações públicas... . Esses versos são 'versos memorandos'.

A finalidade mnemônica encontrou na rima e na versificação acentual intensiva em latim medieval um eficaz meio pedagógico.

\section{Provérbios latinos medievais rimados: exemplos de temáticas}

O corpus de Werner apresenta, após o trabalho de seleção do material, um repositório de parêmias, cuja incidência de determinados eixos temáticos corroboram a hipótese de uma funcionalidade didático-moralizante das expressões proverbiais dentro da sociedade do baixo medievo por nós estudada.

A tradição fabulística de Esopo, Fedro e Aviano legou à humanidade o uso de animais como imagens refletidas, metáforas do próprio homem, com seus sentimentos nobres e vis. Joyce E. Salisbury em The beast within. Animals in the Middle Ages salienta o papel dos animais para o próprio autoconhecimento do homem, pois quando "... as pessoas podem ver um animal agindo como um homem, a metáfora pode ser eficaz nos dois sentidos, revelando o animal dentro de cada ser humano." (1994, p. 105). Intelectuais medievais como Babrius, Marie de France, Odo de Cheridon, homens e mulheres da Igreja, divulgavam estórias sobre animais que supostamente instavam as pessoas a uma conduta moral superior $(1994$, p. 105).

Várias foram as funções dos animais presentes nos textos medievais. Essencialmente, as principais referiam-se a eles como símbolos do trabalho, de comida e de paródia ao comportamento humano. Dentre eles, temos o lobo, a raposa, o leão, o cão, o cordeiro, a serpente, o boi, o sapo, o burro, o macaco, o gato, a cegonha, o esquilo e o veado. Dos animais imaginários, abundantes também na literatura da época, temos o unicórnio, o dragão e seres ambíguos (metade ser humano, metade animal), como o centauro e a sereia. ${ }^{2}$

Os animais, portanto, veiculavam mensagens que serviam para a reflexão do ouvinte/leitor (se adotarmos a dualidade produção escrita, destinada a um público litteratus $\mathrm{X}$ oralidade, presente, por exemplo, na homilias e sermões), mensagens essas que estavam imbuídas de uma sabedoria experiencial aliada à sabedoria primeira oriunda do conhecimento e aplicação diária da palavra de Deus.

A palavra bíblica assumia o papel de instância primeira e última para o homem medieval. Como ponto de partida, as Sagradas Escrituras e como ponto de chegada a própria

\footnotetext{
Não trataremos nesse artigo dos animais mitológicos.
} 
vida, por elas regulamentada de acordo com a interpretação da Igreja. Como afirma Cláudia Montillo (1993, p. 84), "a Idade Média, dividida entre o pecado e a salvação, embebida do maniqueísmo que sempre impregnou o Cristianismo, familiarizava-se facilmente com os ensinamentos bíblicos". Os exemplos de Cristo, dos santos e dos papas serviam de guias práticos de moral. Naqueles tempos, ser sábio era seguir e usar em sua vida diária a palavra de Deus, Verbo fundador do universo e interpretado pela mater ecclesia, como bem caracteriza Johan Huizinga (s.d., p. 221):

Quando o homem da Idade Média quer conhecer a natureza ou a razão duma coisa não a observa para lhe analisar a estrutura íntima, nem para inquirir sobre as suas origens; olha antes para o céu, onde ela brilha como idéia. Quer se trate duma questão política, moral ou social, o primeiro passo a dar é reduzi-la sempre ao seu princípio universal.

A tradição paremiológica cristã iniciou-se com os Provérbios de Salomão, cuja data de redação é incerta. ${ }^{3}$ Este livro demonstra que a aliança do homem com Deus pode ser feita através do conhecimento, aplicação e temor para com Ele. Cultivar sentimentos nobres é a chave da sabedoria. Como diz Derek Kidner (1992, p. 31), é necessário

ser bom para ser sábio - embora Provérbios se ocupe especialmente em indicar o outro lado disto: que é necessário ser sábio para ser realmente bom, pois a bondade e a sabedoria não são duas qualidades que se pode separar: são dois aspectos de uma só unidade. Levando o assunto até às suas origens, é necessário ser piedoso para ser sábio; e isto não é porque a piedade traz vantagens, mas porque a única sabedoria através da qual se pode tratar das coisas da vida diária conforme a natureza delas é a sabedoria através da qual foram divinamente feitas e ordenadas.

Com a incorporação do legado cultural clássico e o desenvolvimento de uma ciência medieval em diversos ramos do saber humano, como Arquitetura, Astronomia, Direito, Filosofia, Gramática, História, Matemática, Medicina, Música e Retórica, dentre outros, a transmissão desse novo conhecimento despertou uma busca à sabedoria, quer através de discussões e debates dentro das universidades e escolas seculares, quer nas ruas e tavernas. Como monumento maior da cultura de então temos a Summa theologica, de São Tomás de Aquino, onde a ciência do homem é embasada pelo conhecimento da sabedoria divina.

Destarte, o homem medieval une o profano ao sagrado para conseguir sabedoria através da religião (etimologicamente "religação"). O sagrado norteia a vida humana e 0 homem (rei ou vassalo, nobre ou clérigo) precisa ter acesso à verdade cristã para poder sobreviver na Terra, enquanto aguarda a eternidade. Em cadernos escolares, os jovens clérigos recebiam, em seus primeiros estudos, provérbios, muitos deles rimados, que continham, em doses diminutas, ensinamentos práticos para a vida. Esses mesmos clérigos, mais tarde padres e monges, proferiam os mesmos diante da massa não litterata para servirem de fio con-

3 Sobre o assunto cf. Kidner (1992, p. 26-7) 
dutor de suas ações. Os provérbios refletiam atitudes, sentimentos, condutas, modos de agir e de pensar que conviriam ou não a um cristão. A mensagem simbólica daqueles expressaria e justificaria o seu uso.

No campo da Literatura, Grécia e Roma forneceram para o mundo medieval europeu autores, temas e personagens. Ovídio, Virgílio, Cícero, Ulisses, Helena, Enéias, Tirésias, Baco, Vênus, dentre inúmeros nomes, entraram para a galeria de personagens medievais como arquétipos de autoridade, astúcia, beleza, coragem, sabedoria, prazeres mundanos e amor. Os compêndios de provérbios medievais as incluem constantemente, representando deuses pagãos ou simples mortais, figuras heróicas ou vilãs, que fazem parte da história universal. Seus comportamentos são motivo de reprimenda ou louvor e caberá ao homem "saber" discernir o que aquelas figuras universais trazem de contribuição para suas vidas no claustro, no palácio e na casa simples.

A alusão a personagens da mitologia greco-romana demonstra, da mesma forma, o trabalho intelectivo com as fontes escritas, onde as mesmas se encontram. No labor dos scriptoria e nas salas de aula e átrios de igrejas e universidades, o elemento cultural pagão é assimilado e compreendido sob uma ótica cristã e exercerá a função de espelhar vícios e virtudes comuns a quaisquer homens, em quaisquer épocas.

A caracterização do papel da mulher dentro da sociedade medieval apresenta-se como extremamente rica em detalhes. Em linhas gerais, podemos vislumbrar dois tipos de posicionamento social em relação à mulher. Sob um primeiro ponto de vista, citando Aurélio González,

temos a visão de padres da Igreja como São João Crisóstomo, Santo Antonino, São João Damasceno ou São Jerônimo, para quem a mulher pode ser soberana peste, porta do inferno, amor do diabo, larva do demônio ou flecha do diabo, posição que indubitavelmente implica na consideração da mulher como fonte do pecado. ${ }^{4}$

A opinião eclesiástica, a princípio, não seria favorável à figura feminina. Uma figura feminina, representada por Eva, tinha conduzido a Humanidade para o pecado, afastando-a do caminho do Criador. Do mesmo modo, porém, Cristo, o redentor da Humanidade pecadora, aquele que veio à terra restituir a união entre filhos e Pai, foi gerado pelo Espírito Santo no ventre de uma mulher virgem e sem máculas, Maria. Este exemplo de mulher poderia resgatar o próprio sexo feminino de sua antepassada pecadora. Sua vida é digna de ser cantada e imitada, tanto em igrejas quanto em cortes, e a união da mulher espiritual com a dama da nobreza impulsiona a produção literária da época.

Como vemos, então, a lírica mariana e o amor cortês enobrecem a mulher. A primeira, por relacionar e ressaltar as qualidades de Maria como mãe de Cristo, tais quais pureza, humildade, bondade, piedade, abnegação, resignação, dentre outras. Maria tornou-se a regina mundi e, paralelamente ao culto mariano, desenvolveu-se em fins do século XI e início do século XII na região da Provença, um tipo de lírica que podemos caracterizar nas palavras

4 In: Company, C.C. (1991, p. 30). 
de Aurélio González (1991, p. 36) como "feudalismo de amor", onde vigorava todo um código de comportamento artificial, estilizado, baseado na humildade, subserviência do homem à mulher e na "cortesia". Da Provença, passando pelas terras do Sacro Império Romano-Germânico, chegando até à Península Ibérica, a lírica trovadoresca e suas canções de amor e de amigo celebravam a mulher e o amor desejado.

Essa figura feminina, entretanto, surgia com frequência nos proverbia medievais simbolizando o mal, razão pela qual acreditamos numa elaboração eclesiástica dos mesmos.

Destarte, a constatação da ocorrência de quatro eixos temáticos, os quais se prendem à utilização de animais como veiculadores de mensagens morais de cunho cristão, parêmias estreitamente ligadas às lições bíblicas, elementos da Antigüidade greco-latina redimensionados, portadores de novas mensagens de fundamentação cristã e provérbios referentes à figura feminina, leva-nos à análise de uma parêmia pertencente a cada grupo, no que concerne, essencialmente, aos principais aspectos literários e culturais pertinentes.

\subsection{Mundo animal}

Provérbio:Dum lupus instruitur in numen credere magnum,

Semper dirigitur oculi respectus ad agnum. (manuscrito B)

Tradução: Enquanto o lobo se instrui em crer em um grande poder,

A atenção do seu olho sempre se dirige para o cordeiro.

A partir do século XII, "os animais tornam-se importantes como metáforas, como guias para as verdades metafísicas, como exemplares humanos". Deste modo, Joyce Salisbury $(199$, p. 103) trata a questão da utilização de animais para representar características humanas.

Neste dístico composto em versos collaterales aparecem dois dos mais importantes animais presentes na simbologia medieval. Por um lado, o cordeiro, dentro do ideário cristão, remete-nos à figura do agnus Dei, o cordeiro de Deus, Jesus Cristo. Joyce Salisbury assim sintetiza a opinião corrente medieval a esse respeito:

Cristo foi tanto o cordeiro de Deus quanto o bom pastor juntando os bons ao rebanho. O cordeiro permaneceu como símbolo para o melhor no autosacrificio conforme a tradição cristã. S. Francisco (sempre simpático a todos os animais) gostava particularmente dos cordeiros, porque, como escreveu seu biógrafo $\mathrm{S}$. Boaventura, os cordeiros "apresentam um reflexo natural da misericordiosa bondade de Cristo e o representam no simbolismo das Escrituras" (1994, p. 132).

Entretanto, uma outra consideração sobre o animal, a partir de um ponto de vista mais ligado à natureza, apresenta-nos o cordeiro como vítima natural de seus predadores, mormente o lobo. Segundo esta perspectiva, as ovelhas e "os cordeiros eram considerados estúpidos e covardes, quase que merecendo aquilo que recebiam" (Salisbury, 1994, p. 132). Por isso, lemos no manuscrito Ba 53, 


\section{Si lupus est agnum, non est mirabile magnum.}

Não nos causa grande admiração, se o lobo come o cordeiro. ${ }^{5}$

O papel do lobo dentro da imagística medieval prende-se ao caráter negativo a ele atribuído. Desde a fábula 1 do livro I de Fedro, cujo título seria Lupus et agnus, já se tomaria conhecimento sobre seu papel de dominador inescrupuloso dos oprimidos. Ele traria injustiça à ordem social em virtude de sua excessiva ganância, que lhe fez perder sua nobreza. Interessante notarmos, como afirma Joyce Salisbury, que o lobo não era criticado por ser predador, já que, "enfim, a guerra - ocupação predatória - era privilégio da classe nobre; era a razão para a sua existência. Aquela classe favorecia seus animais de caça acima de todos os outros ..." (1994, p. 130). Todavia, a insaciável voracidade retiraria prestígio do animal. A pesquisadora americana assim cita a fábula medieval do pregador e do lobo, que bem explicita o caráter de insaciabilidade do canis lupus:

Nesta fábula, um pregador tenciona ensinar ao lobo o alfabeto (talvez para melhorar seu caráter). O lobo concentra muito tempo seus esforços para alcançar a letra $\mathrm{C}$, mas quando ele é perguntado sobre o que deveria pronunciar, ele responde "cordeiro", revelando que sua mente não tinha se libertado do seu estômago.(1994, p. 130-1)

Este texto, portanto, segundo a autora, mostraria a ameaça à hierarquia medieval, a qual

punha a nobreza no topo, e essa ameaça era o que os fabulistas criticavam em suas representações dos homens agindo como lobos. Eles não advogavam violar uma ordem social na qual regiam os predadores nobres, porém tentavam insistir na moderação, a qual, após tudo isso, seria o único jeito de preservar uma tal ordem social. (1994, p. 131)

A denúncia, por fim, associaria então os cordeiros aos menos favorecidos e os lobos aos mais abastados, como se depreende do final da seguinte fábula de Marie de France:

O lobo então apanhou o tão pequeno cordeiro, Estraçalhou o pescoço, tudo extinguiu.

Eles [as pessoas ricas] retiram daqueles [dos pobres] carne $\mathrm{e}$ Pele,

Como o lobo fez com o cordeiro. ${ }^{6}$

5 Repare-se na forma arcaica do verbo esse, "comer", o que demonstra o conhecimento da história da língua latina por parte do autor da expressão.

6 Cf. Salisbury, 1994, p. 132. 


\subsection{Igreja}

Em terras do Sacro Império Romano-Germânico sentiam-se os ecos de vozes de protesto. Encontramos ao longo do corpus de Werner exemplos de provérbios que trazem à luz uma imagem negativa dos prelados. No manuscrito B 74 lê-se Roma capit marcas, bursas exhaurit et archas; / Ut tibi te parcas, fuge papas et patriarchas, "Roma pega o dinheiro, exaure as bolsas e as arcas; / Para que tu te poupes disto, foge dos papas e dos patriarcas" e no manuscrito B lê-se Scire bonos mores fuit olim gloria cleri / Et laus magna fuit vitam sine labe tueri, isto é, "Conhecer bons costumes foi outrora a glória do clero/ E o maior louvor foi manter a vida sem mácula".

A primeira parêmia, em versos unisoni, menciona diretamente Roma, a ainda caput mundi, sede do poder papal, cuja administração estava entregue à Cúria. A possibilidade de resolução de alguma querela jurídico-política através dos membros do estado pontifício existia, caso houvesse meios pecuniários que pudessem ser postos à disposição dos prelados. A palavra marcas, "moedas", delimita o espaço geográfico do mundo germânico, na medida em que situa o autor da parêmia como procedente daquelas regiões, cujo território tinha sido, três séculos e meio antes, objeto de disputa entre papado e império no caso da questão das investiduras.

O problema da investidura leiga dos prelados levou o papa Gregório VII (1073-1085) a tentar restaurar, de uma vez por todas, a independência do episcopado. Como afirma Daniel Ribeiro (1995, p. 55), o novo pontífice desejava "libertar o clero de toda a tutela a fím de que, sob a direção da Igreja, possa controlar as diversas atividades da sociedade; a submeter o conjunto da Igreja a um único poder - o papado -, que goza do privilégio de definir a fé e reúne a todos sob sua autoridade soberana".

Contrapondo-se a tal objetivo está a política dos imperadores sálicos, especialmente, naquela época, a de Henrique III, que investia bispos conforme a sua conveniência e proveito próprio. O conflito era inevitável e em 1076 o imperador, no sínodo de Worms, integrado por bispos alemães, chega a pedir a deposição do papa, sendo por isso mais tarde excomungado pelo pontífice e tendo seu poder imperial retirado. O fato, porém, de maior importância nessa contenda foi a resolução de Gregório em dispensar os súditos cristãos de obediência ao soberano teutônico. Foi escolhido Rudolf von Schwaben para suceder ao deposto soberano, que sem o apoio dos seus súditos cristãos, vai a Canossa em janeiro de 1077 para fazer a reconciliação com o pontífice e ter sua excomunhão suspensa. Em 1122, na Concordata de Worms, foram fixados os parâmetros finais para tal disputa, já que "a investidura leiga cabia ao poder temporal e a cerimônia de concessão da cruz e do anel era exclusiva da autoridade espiritual. Ratificava-se, assim, o poder dos Fürstbischöffe, "bispos-principes", autoridades eclesiásticas que também possuíam a espada temporal, respeitando o rei e obedecendo ao papa.

Como se evidencia, então, no provérbio $n^{\circ} 74$ de Basel, os bens terrenos atraíam a cobiça de Roma, de tal forma que nem os mais humildes nem os mais abastados - caracterizados pelas bursas, "bolsas", forma latinizada do grego byrsas e archas, "arcas" - são poupados, culminando no conselho final para que se evite a todo o custo as figuras máximas do Cristianismo, aqui representadas pelo papa, pelo lado do catolicismo ocidental, e pelo patriarcha, chefe da igreja ortodoxa de rito grego, pois estes cultuariam mais a lei dos bens do mundo e não tanto a palavra do Criador. 
O segundo provérbio, em contrapartida, possui um tom saudosista, na medida em que atribui ao clero de tempos passados um conhecimento dos bons costumes, os quais se prendem logicamente à observância e ao respeito da doutrina cristã consoante os ensinamentos da Igreja. Uma vida sem máculas podia ser observada, diretamente experienciada nos membros eclesiásticos, o que provavelmente nos tempos do autor do dístico em versos caudati não ocorria. Enfim, a caracterização do clero como afastado ou negligente em suas funções de guardião e propagador da mensagem cristã católica está perfeitamente espelhada nesses provérbios oriundos de terras germânicas.

\subsection{Elementos da Antigüidade Clássica}

Provérbio: Qui studium spernit simul et tua carmina, Naso!

Nil sibi contingat melius quam fiat agaso. (manuscrito B)

Tradução: Quem ao mesmo tempo despreza o estudo e os teus versos, Nasão!

Não tenha sorte melhor do que tornar-se lacaio.

Publius Ovidius Naso nasceu em Sulmona no ano 43 a.C. e faleceu aos 63 anos de idade no ano 18 da nossa era. Sua extensão produção literária - desde a epistolografia até sua obra poética - era alvo de estudos desde a Alta Idade Média. O talento artístico e o preciosismo literário do poeta foram redescobertos pelos lectores medievais. Konrad von Hirsau - primeira metade do século XII - aceita a leitura dos Fasti e das Epistolae ex Ponto, recusando as obras eróticas e as Metamorphoses. ${ }^{7}$ Por outro lado, no final deste mesmo século, Alexander Neckam (apud Curtius, 1957, p. 52) admite a leitura das Metamorphoses e para combater os seus possíveis efeitos, os Remedia amoris. Seus poemas são analisados à luz de artifícios retóricos, pois "sua poesia deleita-se com antíteses e agudezas, efeitos de eufonia e sentido". (apud Curtius, 1957, p. 68). No século XIV, cabe mencionar que as Metamorphoses ganharam uma versão moralizada, elaborada por Pierre Bersuire (Petrus Bercorius), sob o título Metamorphosis Ovidiana moraliter explanata, que teve sua primeira edição publicada em 1340 e a segunda no ano de 1342. Todavia, um outro aspecto importante do trabalho com seus textos possibilitou aos clerici deles depreender expressões proverbiais, as quais tiveram largo uso durante o medievo.

Da Literatura para a Retórica, entremeado de exemplos moralizantes, Ovídio foi uma das auctoritates mais significativas dentro do universo intelectual medieval. Tal assertiva pode ser defendida, se atentarmos para o provérbio do manuscrito de Basel, em versos caudati, onde o vocábulo nil aparece grafado sem os grafemas - $h i$ - da forma clássica nihil, tendência essa já constatável a partir do sermo vulgaris. No que tange explicitamente à parêmia, notamos que a referência ao poeta de Sulmona se inicia praticamente com a equivalência entre o studium, entendido como o ingresso na universidade, e o conhecimento dos versos de Ovídio, o que confirma ser sua leitura indispensável pelo menos para o curso das disciplinas do trivium. Caso, contudo, seu estudo seja negligenciado ou propositalmente

Cf. Curtius, 1957, p. 52. 
rejeitado, triste sina estará reservada ao autor de tal temeridade, pois não obterá posição de destaque dentro da sociedade medieval, cabendo-lhe possivelmente o papel de lacaio.

Neste ponto, este provérbio mostra-se extremamente rico em considerações de ordem social sobre o medievo, a saber:

a) no estudo universitário, a leitura dos carmina ovidianos era indispensável;

b) o conhecimento delas advindo poderia futuramente proporcionar ascensão social no fechado universo do baixo medievo;

c) o desconhecimento das obras do sulmonês, em contrapartida, poderia determinar uma posição de inferioridade no âmbito do saber e a palavra agaso, "lacaio", pode perfeitamente ser aplicada quase como sinônima de vassalus.

Uma segunda parêmia em versos caudati lembra o sofrimento de Nasão por ter sido expatriado por Augusto: Dicas, cum pateris, que forsan non meruisti: / Hec modo Naso feres, quoniam maiora tulisti, - manuscrito $\mathbf{B}-$. "Que tu digas, quando sofreres coisas que talvez não mereceste:/ Suportarás logo estas coisas, Nasão, visto que suportaste maiores". Visualiza-se por trás da menção aos sofrimentos de Ovídio uma mensagem de reconforto, pois muitas vezes cometem-se injustiças e pessoas inocentes são as vítimas expiatórias das mesmas.

Como não perceber aqui, então, a palavra cristã do encorajamento à prática da abnegação, pois se o Mestre dos Mestres padeceu sob as injustas acusações dos fariseus, a tudo aceitando, pois estava cônscio de que daquela forma cumpriria a vontade de seu Pai, ele, Ovídio, um mortal, como se acabasse de adentrar a época do autor da parêmia, deveria mirar-se no exemplo de Cristo e aguardar a sua misericórdia. A intertextualidade entre os textos de Ovídio e a Sagrada Escritura revela-se, pois, presente no século XV, fazendo com que o poeta de Sulmona, cidadão romano, possa ser ornado quatorze séculos depois com as virtudes de um cristão.

\section{A mulher}

$\mathrm{Na}$ Baixa Idade Média, encontramos o provérbio 14 em verso leonino no manuscrito de Sankt Gallen, onde o corpo feminino se torna receptáculo do demônio: Femina vas sathane, rosa fetens, dulce venenum / Semper prona rei, que prohibetur ei, "A mulher é o vaso de Satanás, uma rosa que fede, um doce veneno / Sempre inclinada para as coisas que lhe são proibidas". Observa-se em sathane e em que a redução do ditongo ae para $e$ das formas do latim clássico sathanae e quae e a monotongação do ditongo clássico oe para $e$ em fetens. Decaída por natureza e por isso mesmo aliada ao demônio, a mulher traz consigo as marcas do caráter fétido de seu ser, do veneno que é inoculado em sua vítima masculina através de seu corpo e de suas palavras insinuantes e de sua predisposição biológica para o mal.

Uma outra parêmia em versos leoninos que reflete a ligação entre a femina e o daemon encontra-se no manuscrito B, Urtica fetidum tergebat femina culum / Dicens hec verba: "puto, quod demon sit in herba", i.e., "A mulher esfregava o fétido cu com a urtiga / Dizendo estas 
palavras: "Imagino que o demônio esteja nesta planta". Neste exemplo no qual a monotongação dos ditongos clássicos ae e oe se repete em hec, demon e fetidum, a figura feminina intenta chamar o demốnio ao passar um galho de urtiga em seu ânus, o que a transforma em uma bruxa. Por isso, ao se aproximar de Satanás, ela se identifica como a sucessora de Eva, renegando os atos de Maria e sua própria fé, como afirmam Kramer e Sprenger, citados por Carlos Roberto Figueiredo Nogueira (1991, p. 106), para propor a etimologia de femina:

Em conseqüência ela mostra que duvida e tem pouca fé na palavra de Deus. E tudo isso é indicado pela etimologia da palavra: pois Femina procede de $\mathrm{Fe}$ e Minus, uma vez que ela é sempre fraca para manter e preservar a fé. Portanto, uma mulher é por sua natureza mais rápida em hesitar em sua fé, e consequientemente mais rápida em abjurar a fé, que é a causa da bruxaria.

Um dos pontos que mais afastariam a mulher dos padrões morais do cristianismo seria sua propensão aos bens materiais. Para adquirir meios de subsistência, não há por parte da mulher meios ilícitos. Assim, no provérbio $20 \mathrm{em}$ verso leonino do manuscrito Ba lê-se Laudat quisque suum: sic laudat femina culum, "Cada um louva o que é seu: assim, a mulher louva seu cu", pois possivelmente ela dele fará instrumento para conseguir angariar fundos para seus projetos pessoais de melhoria de vida. A advertência da voz proverbial contra a astúcia feminina para obter recursos faz-se sentir mais claramente na parêmia 6 em verso leonino do manuscrito Ba, Basiat armigerum femina propter erum, ou seja, "A mulher beija o escudeiro por causa do seu senhor". No plano do discurso, a "fêmea" procura relacionar-se com o escudeiro de algum cavaleiro ou senhor feudal, para poder se aproximar deste último, fazer-se conhecida, chamar sua atenção e conquistá-lo, perfazendo assim um círculo de sedução, cujo objetivo seria no final das contas apropriar-se de parte de suas riquezas.

Em suma, a figura da femina é motivo de alerta para os vigilantes viri. Estes, portadores das virtudes de um cristão, estarão prontos para esperar pelas multifacetadas atitudes femininas, que visam o próprio ego, Vulpes vult fraudem, lupus agnum, femina laudem manuscrito Ba 73 -. "A raposa quer o logro, o lobo o cordeiro, a mulher o louvor" e os lucros que podem auferir a partir de sua natureza sedutora, carnal e astuciosa. Em conluio com o demônio, a mulher torna-se, portanto, um adversário do homem, e stultus será aquele que nela confiar. Todavia, o homem imbuído do espírito de Deus e da palavra da Igreja a ela resistiria, sendo, porém, motivo de acre reprimenda e de perigosa desestruturação social o fato de o varão aceitá-la e segui-la, pois como expõe a parêmia $20 \mathrm{em}$ verso leonino do manuscrito Ba, Res mala vir malus est; mala femina pessima res est, "Uma coisa má é um homem mau; uma coisa péssima é uma mulher má".

\section{Considerações finais}

A produção fraseológica medieval em latim, com sua variada gama de recursos estilísticos,oferece, pelo que se pôde constatar, um amplo panorama sócio-cultural sobre a Idade Média, uma produção rimada, normalmente em hexâmetros e pentâmetros, com vá- 
rios tipos de versos, e que tem como base precípua a manutenção da ordem social de estrutura teocêntrica da vida medieval.

Os provérbios, como fonte de sabedoria, têm nos textos da Sagrada Escritura e de autores eclesiásticos fontes continuamente compiladas, estudadas e adotadas pelos homens da Igreja durante a época medieval. Esta, por sinal, fruto do desmembramento político e, conseqüentemente cultural, do mundo clássico, (em especial do mundo romano) atravessou séculos de constantes mudanças político-sociais até o advento de Carlos Magno em 768, época em que foram lançadas as pedras fundamentais para um novo incremento à cultura, onde o latim se tornou a ferramenta dos letrados. A partir do século XII, as escolas eclesiásticas e as universidades dinamizam a transmissão do conhecimento do novo, com uma sólida base cristã, aliada ao antigo legado clássico, com as artes liberales moldando o intelectual deste tempo. A rima presta-se muito bem à estratégia de internalização mnemốnica e aconselhável utilização no dia-a-dia, o que denota sua função eminentemente propedêutica. $O$ material paremiológico configura-se em um dos mais sólidos alicerces do discurso ideal dos valores cristãos defendidos pela alta hierarquia da Igreja.

Sabedoria e experiência, teoria e prática, pois, caminham lado a lado nos provérbios, formas didáticas de fundo moralizante. "Estratégias para situação", preparação para uma praxis concernente com a voluntate Dei como assevera James Obelkevich em seu artigo Proverbs and Social History:

O que define o provérbio, entretanto, não é seu desenho externo mas sua função externa, e aquele, geralmente, é moral e didático: as pessoas usam provérbios para dizer a outras o que fazer em uma dada situação ou que atitude tomar diante dela. Provérbios, então, são 'estratégias para situações'; mas eles são estratégias com autoridade, que formulam uma parte de um senso comum da sociedade, seus valores e modo de fazer as coisas. ${ }^{8}$

Portanto, educere e sapere perpassam a estrutura formal e semântica do provérbio medieval em latim, marca de uma visão do mundo consoante com os desígnios da mater ecclesia.

\section{Referências Bibliográficas}

BRAGANÇA JÚNIOR, Álvaro Alfredo. A fraseologia medieval latina como reflexo de uma sociedade. Rio de Janeiro: Faculdade de Letras da UFRJ. Tese de Doutorado em Língua e Literatura Latina. 1998. 204 páginas (Inédito).

COMPANY, Concepción Company. (Edit.) Amor y cultura em la Edad Media. México: Universidad Nacional Autónoma de México, Instituto de Investigaciones Filológicas, 1991.

8 apud Mieder (1994, p. 213). 
CURTIUS, Ernst Robert. Literatura européia e idade média latina. Tradução de Teodoro Cabral. Rio de Janeiro: Instituto Nacional do Livro, 1957.

GRYZBEK, Peter. Sinkendes Kulturgut? Eine empirische Pilotstudie zur Bekanntheit deutscher Sprichwörter. /Sem indicações bibliográficas/.

\& CHLOSTA, Christoph. Grundlagen der empirischen Sprichwortforschung. In: MIEDER, Wolfgang (Hrsg.) Proverbium 10. Vermont: The University of Vermont, 1993, p. $89-128$.

HÉLIN, Maurice. La litterature latine au Moyen Age. Paris: PUF, 1972. [Que sais-je?, v. 1043].

HUIZINGA, Johan. O declínio da Idade Média. Tradução de Augusto Abelaira. Lisboa: Ulisséia, /s.d./.

KIDNER, Derek. Provérbios. Introdução e Comentário. São Paulo: Sociedade Religiosa Edições Vida Nova \& Associação Religiosa Mundo Cristão, 1992.

LANGOSCH, Karl. Lateinisches Mittelalter. Einleitung in Sprache und Literatur. Darmstadt: Wissenschaftliche Buchgesellschaft, 1988.

MIEDER, Wolfgang. (Edit.) Wise words. Essays on the proverb. New York, London: Garland Publishing, Inc, 1994.

MONTILLO, Cláudia de Cássia Capello. A voz e os ecos - medievalismo e atualidade n'O livro de Esopo. Rio de Janeiro: Universidade Federal do Rio de Janeiro, Faculdade de Letras, 1993. 241 fls. mimeo. Dissertação de Mestrado em Literatura Portuguesa.

NOGUEIRA, Carlos Roberto Figueiredo. Bruxaria e história. As práticas mágicas no Ocidente cristão. São Paulo: Ática, 1991.

OBELKEVICH, James. Proverbs and social history. In: Wise words. Essays on the proverb. Edited by Wolfgang Mieder. New York, London: Garland Publishing, Inc., 1994, p. 21152.

OTTO, A. Die Sprichwörter und sprichwörtlichen Redensarten der Römer. 2. Aufl. Hildesheim: Georg Ohlms Verlag, 1971.

RIBEIRO, Daniel Valle. Igreja e estado na Idade Média. Relações de poder. Belo Horizonte: Editora Lê, 1995.

SALISBURY, Joyce. The beast within. Animals in the Middle Ages. New York; London: Routledge, 1994.

WERNER, Jakob. Lateinische Sprichwörter und Sinnsprüche des Mittelalters. Heidelberg: Carl Winter's Universitätsbuchhandlung, 1912.

BRAGANÇA JÚNIOR, Álvaro Alfredo. Considerations on the education through the proverbs in latin during the Low Middle Ages. Classica, São Paulo, v. 15/16, n. 15/16, p. 215-230, 2002/2003. 

dos provérbios em latim na Baixa Idade Média.

schools until the system of the artes liberales in the universities. However, one of the most efficient methods of passing on the cultural rudiments to the disciples, specially to them from the Low Middle Ages, was based on the compilation of school exercises, usually in form of rhymed distichs, which present a highly theological justification as to the commandments of the Church. Those future clerici, instructed by such a cultural pattern, would be able, on the pulpits, to preach the doctrines passed by their masters. Thus, as a result of it, it was enabled an oral proverbialization of such written texts according to a daily practice, in which docere and scire, together with posse, formalized, through this instructional model, the ideals of the Papal Court.

KEYWORDS: Maediaeval Paremiology; Mediaeval Latin; Low Middle Ages in German speaking regions; Mediaeval Church; History of Education. 